
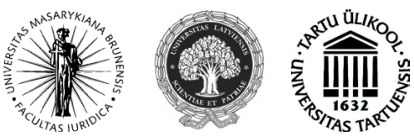

ISSN 1392-6195 (print) ISSN 2029-2058 (online) JURISPRUDENCIJA JURISPRUDENCE 2014, 21(1), p. 115-140.

\title{
VIEŠOJO INTERESO NUSTATYMAS - OBJEKTYVIEJI KRITERIJAI
}

\author{
Evaldas Klimas \\ Mykolo Romerio universiteto Teisès fakulteto \\ Verslo teisès katedra \\ Ateities g. 20, LT-08303 Vilnius, Lietuva \\ Telefonas (+370) 62036055 \\ Elektroninis paštas evaldas.klimas@lawin.lt \\ Julius Lankelis \\ Mykolo Romerio universiteto Teisès fakulteto \\ Verslo teisès katedra \\ Ateities g. 20, LT-08303 Vilnius, Lietuva \\ Telefonas $(+370) 60358006$ \\ Elektroninis paštas julius.lankelis@veto.lt
}

Pateikta 2014 m. vasario 10 d., parengta spausdinti 2014 m. kovo 13 d.

doi:10.13165/JUR-14-21-1-06

\section{Ivadas}

Teismams labai dažnai tenka spręsti viešojo intereso gynimo problemą. Dažniausiai teismų sprendimuose, nagrinėjant bylas, kuriose įžvelgiami viešojo intereso elementai, neišvengiamai analizuojamas ir viešojo intereso gynimas, ir paties viešojo intereso samprata, inter alia, nagrinëjamas viešojo intereso santykis su konstituciniais teisètų lūkesčių, teisinio (ir socialinio) stabilumo, tikrumo bei saugumo principais,

Jurisprudencija/Jurisprudence

(C) Mykolo Romerio universitetas, 2014

(C) Mykolas Romeris University, 2014
ISSN 1392-6195 (print), ISSN 2029-2058 (online) http://www.mruni.eu/lt/mokslo_darbai/jurisprudencija/ http://www.mruni.eu/en/mokslo_darbai/jurisprudencija/ 
taip pat bendraisiais teisès principais - teisingumo, sąžiningumo bei proporcingumo. Deja, praktikoje neretai susiklosto situacijos, kai nacionaliniai teismai, nors ir vadovaudamiesi (teismų sprendimuose cituojant) precedentiniais Lietuvos vyriausiojo administracinio teismo (toliau - LVAT), Lietuvos Aukščiausiojo Teismo (toliau LAT) ir Lietuvos Respublikos Konstitucinio Teismo (toliau - LRKT) išaiškinimais, susijusiais su viešojo intereso gynimu bei jose suformuluotomis teisès aiškinimo ir taikymo taisyklèmis, priima kardinaliai skirtingus sprendimus. Galima to priežastis egzistuoja giluminès viešojo intereso suvokimo (interpretavimo) problemos.

Šios studijos tikslas (kiek leidžia ribota straipsnio apimtis) - išskirti pagrindinius objektyviuosius viešojo intereso determinantus, ịvertinus viešojo intereso sampratos doktrinas bei aukščiausios grandies teismų suformuotus precedentus. Tai turètų būti itin naudinga teisés praktikams, bent jau kol nẻra naujausių teismų praktikos apibendrinimų arba metodikų ${ }^{1}$, analizuojančių viešojo intereso nustatymo apibrèžtị (gaires).

Rengiant šị darbą taikyti dokumentų tyrimo analizės ir sisteminimo metodai. Tyrimo objektą sudaro viešojo intereso sampratos analizė teisės doktrinoje, naujausi aukščiausios grandies teismų (LVAT, LAT, LRKT), Europos Žmogaus Teisių Teismo (toliau - EŽTT) precedentai. Atliekant tyrimą papildomai taikyti teleologinis bei lyginamasis metodai.

Šios studijos naujumas yra tai, kad analizuojant naujausius teismų precedentus bandoma išskirti pagrindinius objektyviuosius viešojo intereso gynimo kriterijus, taip papildant studijas viešojo intereso gynimo klausimais, kurias yra atlikę A. Driukas, E. Krivka, E. Kūris, U. Trumpulis, V. Nekrošius ir kiti teisès mokslininkai.

\section{Viešojo intereso apibrèžtis}

Kas yra viešasis interesas, nei nacionaliniai teisès aktai, nei nacionalinių teismų praktika expressis verbis neapibrèžia, o teisès doktrinoje vyrauja nuomonè, kad viešojo intereso kategorijos turinio apibrěžti apskritai neįmanoma arba labai sunku².

12006 m. sausio 19 d. Lietuvos Respublikos generalinio prokuroro įsakymu Nr. I-11 patvirtintos Metodinès rekomendacijos viešajam interesui ginti, šio straipsnio autorių nuomone, ne itin atitinka pasikeitusias šiandienos realijas.

2 Drakšas, R. Viešojo intereso gynimas: praktika ir problemos. Lietuvos advokatūra. 2012, 4 (45): 3; Kūris, E. Viešasis interesas: teisėkūra ir konstitucinè jurisprudencija. Notariatas. 2012, 13: 48; Driukas, A.; Valančius, V. Civilinis procesas: teorija ir praktika. I tomas. Vilnius: Teisinès informacijos centras, 2005, p. 669; Krivka, E. Viešojo intereso gynimas civiliniame procese. Vilnius: Mykolo Romerio universitetas, 2009, p. 42; Nekrošius, V. Viešojo intereso gynimas civiliniame procese ir Konstitucinio Teismo doktrina. Jurisprudencija. 2012, 19(3): 1105; Trumpulis, U. Viešojo intereso koncepcijų ịvairove ir jų vertinimas. Jurisprudencija. 2010, 4(8): 218; Klimas, E.; Brazdeikis, A. Visuomenès (viešojo) intereso gynimas planuojant teritorijas. Viešojo intereso gynimas: subalansuoto požiūrio link. Vilnius: Vilniaus universiteto leidykla, 2013, p. 124; Rekosh, 
Viešojo intereso kategorija - universali, t. y. apimanti beveik bet kurią visuomeninių santykių sferą. Tai reiškia, kad viešojo intereso kategorijos turinys priklauso nuo to, kurios mokslo šakos - ekonomikos, sociologijos, psichologijos, filosofijos, politologijos ar teisès - tyrèjas šią sąvoką bando apibrèžti. Užsienio teisès doktrinoje, prieš bandant apibréžti viešojo intereso sampratą, pagrịstai keliamas klausimas, o kas apskritai, t. y. kurios profesijos atstovas ir kieno interesų vedamas bando apibrèžti viešojo intereso sąvoką ${ }^{3}$. Suprantama, kad politikų formuojama viešojo intereso samprata yra orientuota i socialinius ir ekonominius procesus (general interest or welfare interest) ir retai kada pasižymi kokiais nors moksliniais kriterijais ar metodais. Tarptautinejje erdvèje (ypač diplomatiniuose santykiuose) viešasis interesas formuojamas per žmogaus teisių ir laisvių prizmę, akcentuojant prigimtines žmogaus teises (pilietybės, dvigubos pilietybės, pabėgèlių statuso klausimai). Sociologijos, psichologijos, ekonomikos moksluose viešasis interesas bandomas apibrèžti taikant tiksliuosius metodus, t. y. tokius metodus, kuriais galima būtų patikrinti tyrimo išvadas ateityje ir gauti tapačius ar bent jau panašius rezultatus. Tačiau daugiausiai diskusijų kelia teisinis viešojo intereso suvokimas, nes tik teisinè viešojo intereso kategorija gali sukurti privalomas elgesio taisykles. Tai, kad viešojo intereso kategorijos turinys yra teisinis, o ne bendrinei kalbai būdingas terminas, akcentuoja ir LVAT ${ }^{4}$.

\subsection{Bandymai pateikti viešojo intereso apibrèžtị}

Viešojo intereso kategorijos klasifikacijos bei apibrèžimų klausimais ịvairiai pasisakoma ir užsienio teisès literatūroje $e^{5}$, tą pastebi ir Lietuvos mokslininkai ${ }^{6}$. Tačiau, šio straipsnio autorių nuomone, įdomus ir aktualus yra viešojo intereso kategorijos klasifikavimas ị dvi dideles koncepcijas - socialinę bei materialinę (normatyvinę) ${ }^{7}$ viešojo intereso koncepcijas.

Socialinès viešojo intereso koncepcijos esmė yra galingų ekonominių interesų spaudimas teisiniam reguliavimui, per kuri siekiama socialinio teisingumo tikslų ${ }^{8}$ arba fundamentalių demokratinių vertybių apsaugos ${ }^{9}$. Tenka pritarti šiam teiginiui,

E. Who defines the public interest? Public interest law stratiegies ir central and eastern Europe. Sur, Rev. int. direitos human [interaktyvus]. 2005, 2(2): 174-175 [žiūrèta 2014-02-01]. < http:// www.scielo.br/scielo.php?pid=S1806-64452005000100008\&script=sci_arttext\&tlng=en>; Feintuck, M. The public interest in regulation. Oxford university press, 2004, p. 213, 248.

3 Rekosh, E., supra note 2, 175-176.

4 Administracine jurisprudencija. Administracinių teismu praktika. Administracinè doktrina. Lietuvos vyriausiojo administracinio teismo biuletenis. 2009, 6 (16): 332.

5 Daugiau žr.: Rekosh, E., op. cit., p. 175-184; Feintuck, M., op. cit., p. 179-255.

6 Trumpulis, U., op. cit., p. 218-220.

7 Rekosh, E., supra note 2, p. 176.

8 Ibid., p. 175-176.

9 Feintuck, M., supra note 2, p. 247. 
juk viešojo intereso kategorija yra aktuali būtent tose socialinio gyvenimo srityse, kuriose pasireiškia ypatingas ekonominis interesas - nuosavybé, imigracija / emigracija, darbo rinka, mokestinès prievolès ir t. t.

Materialinè (normatyvinè) viešojo intereso kategorija turètų būti grindžiama teisiniais ex ante apibrěžtais terminais ar kriterijais. Tačiau iki šiol vieningos ir visiems priimtinos teisinès viešojo intereso kategorijos, deja, nèra. Šio straipsnio autoriai pastebi, kad Lietuvos teisineje mintyje, atsižvelgiant ị anksčiau išsakytą mintị apie subjektus formuojančius viešojo intereso kategoriją, teisiniu požiūriu yra išskirtini i̊statymų leidejjas bei teismai.

Istatymų leidejjas, kaip subjektas, kuris formuoja viešojo intereso kategoriją, nors ir ekvilibristiškai, tačiau jau kelis kartus yra išreiškęs ambicijas ị viešojo intereso kategorijos sunorminimą. Pasakytina, jog įstatymų leidejjas, siekdamas pateikti sunormintą viešojo intereso apibrežtị, veikia nesistemingai - vienais atvejais viešojo intereso kategorijos apibrěžimo apskritai nepateikia, pavyzdžiui, Prokuratūros ịstatymo ${ }^{10}$ 19 straipsnis, Civilinio proceso kodekso ${ }^{11}$ 150, 320, 353 straipsniai, Civilinio kodek$\mathrm{so}^{12} 2.125$ straipsnio 2 dalis, 6.225 straipsnis, kitu gi atveju, pavyzdžiui, naujos redakcijos Teritorijų planavimo ịstatymo 8 straipsnio 1 dalyje, yra bandoma išskirti visuomenès (viešojo) intereso planuojant teritorijas apibrežżị ${ }^{13}$. Tikslią sąvokos apibrežtị bandoma pateikti ir Viešojo intereso gynimo civiliniame ir administraciniame procese įstatymo projekto Nr. XP-1963 1 straipsnio 2 dalyje (šis projektas nuolat tobulinamas, o paskutiniu metu atsirado siūlymų iš esmès koreguoti 1 straipsnio 2 dalyje pateikiamą viešojo intereso kategoriją įvedant kokybinius ir kiekybinius kriterijus) $)^{14}$. Be kita ko, kaip teisingai pažymejjo E. Kūris ${ }^{15}$, nors ir itin siaurame socialinių santykių rate, expressis verbis viešojo intereso apibrežti galima įžvelgti Viešųjų ir privačių interesų derinimo valstybinejje tarnyboje įstatymo 2 straipsnio 3 dalyje ${ }^{16}$. Specifinis viešojo intereso kategorijos apibrèžimas taip pat pateiktas Vartotojų teisių apsaugos istatymo ${ }^{17} 30$ straipsnio 2 dalyje. Dèl tokios ịstatymo leidejo pozicijos viešojo intereso

10 Lietuvos Respublikos prokuratūros ịstatymas. Valstybès žinios. 2003, Nr. 42-1919.

11 Lietuvos Respublikos civilinio proceso kodeksas. Valstybès žinios. 2002, Nr. 36-1340.

12 Lietuvos Respublikos civilinis kodeksas. Valstybès žinios. 2000, Nr. 74-2262.

13 Lietuvos Respublikos teritorijų planavimo ịstatymas. Valstybès žinios. 2013, Nr. 76-3824.

14 Lietuvos Respublikos Seimo nario Remigijaus Žemaičio 2012 m. balandžio 2 d. pasiūlymas dèl viešojo intereso gynimo civiliniame ir administraciniame procese ịstatymo projekto Nr. XP-1963 [interaktyvus]. [žiūrèta 2014-02-01]. <http://www3.lrs.lt/pls/inter3/dokpaieska. showdoc_l?p_id=421616>.

15 Kūris, E., supra note 2, p. 51.

16 Lietuvos Respublikos viešųjų ir privačių interesų derinimo valstybinẻje tarnyboje įstatymas. Valstybès žinios. 2000, Nr. 18-431.

2 str. 3 d.: „Viešieji interesai - visuomenès suinteresuotumas, kad asmenys, dirbantys valstybinëje tarnyboje, visus sprendimus priimtų nešališkai ir teisingai.“

17 Lietuvos Respublikos vartotojų teisių apsaugos ịstatymas. Valstybès žinios. 1994, Nr. 94-1833. 
gynimo klausimai netampa nei aiškesni, nei nuoseklesni. Inter alia, visi bandymai îstatymu eksplicistiškai apibrèžti viešojo intereso kategoriją yra itin kritikuojami teisès moksle, pavyzdžiui, teigiama, kad Teritorijų planavimo ịstatyme pateikta visuomenès (viešojo) intereso apibrèžtis yra tokia plati, kad ji praktikoje gali sukelti daugiau klausimų, nei padèti išspręsti egzistuojančias problemas, o ịtvirtinus platų viešojo (visuomenès) intereso turinio elementų sąrašą, kartais net gali būti laikoma, kad ịtvirtinti elementai prieštarauja vienas kitam $^{18}$. Iš esmès tokios pat pozicijos laikosi ir kiti autoriai kritikuodami viešojo intereso kategorijos apibrěžtis, ịtvirtintas kituose anksčiau minètuose įstatymuose ${ }^{19}$.

Nacionalinė teismų praktika vienareikšmiškai teigia, kad ịstatymų leidejjas nepateikè universalios ir aiškios viešojo intereso kategorijos apibrěžties, todèl kiekvienu individualiu atveju teismai turi spręsti klausimą, ar interesas, j̣ kurị kèsinamasi, pripažintinas viešuoju interesu, t. y. teismai kiekvieną kartą ad hoc nustato viešojo intereso (ne)buvimo faktą, atsižvelgdami ị visas konkrečios bylos aplinkybes ${ }^{20}$. Tokios pozicijos laikosi tiek LRKT ${ }^{21}$, tiek LAT $^{22}$, tiek LVAT. To pasekmè - viešojo intereso bylos iš esmès yra kazuistinio pobūdžio. Nacionalinèje teismų praktikoje laikoma, kad viešasis interesas egzistuoja įvairių kategorijų bylose, pavyzdžiui: bylos, susijusios su nusikaltimų kardymu, jų tyrimu ir nustatymu ${ }^{23}$; žmonių sveikatos apsauga ${ }^{24}$; daugiabučių namų tinkamu eksploatavimu bei jų išsaugojimu ${ }^{25}$; autoriaus teisių ir interesų pažeidimais ${ }^{26}$; aplinkos apsauga ir teritorijų planavimu ${ }^{27}$; tinkamu teisès normų

18 Daugiau apie visuomenès (viešojo) intereso elementus planuojant teritorijas žr. Klimas, E.; Brazdeikis, A., supra note 2, p. 118-139.

19 Krivka, E. Viešojo intereso gynimo civiliniame procese reglamentavimo problemos. Jurisprudencija. 2008, 2(104): 50; taip pat Kūris, E., supra note 2, p. 51.

20 Administracine jurisprudencija. Administraciniu teismu praktika. Administraciné doktrina, supra note 4, p. 332.

21 Lietuvos Respublikos Konstitucinio Teismo 2006 m. rugsèjo 21 d. nutarimas „Dèl teismų sprendimų motyvų surašymo ir skelbimo, sprendimo už akių, taip pat apeliacijos“. Valstybės žinios. 2006, Nr. 102-3957.

22 Lietuvos Aukščiausiojo Teismo Civilinių bylų skyriaus $2013 \mathrm{~m}$. vasario 22 d. nutartis civilinèje byloje Nr. 3K-3-40/2013.

23 Lietuvos Respublikos Konstitucinio Teismo 2002 m. rugsèjo 19 d. nutarimas „Dèl Telekomunikacijų, Operatyvinès veiklos ịstatymų ir Baudžiamojo proceso kodekso“. Valstybès žinios. 2002, Nr. 93-4000.

24 Lietuvos Respublikos Konstitucinio Teismo $2002 \mathrm{~m}$. kovo 14 d. nutarimas „Dèl farmacinès veiklos“. Valstybès žinios. 2002, Nr. 28-1003.

25 Lietuvos Respublikos Konstitucinio Teismo 2000 m. gruodžio 21 d. nutarimas „Dèl narystès daugiabučių namų savininkų bendrijose“. Valstybès žinios.2000, Nr. 110-3536.

26 Lietuvos Respublikos Konstitucinio Teismo $2000 \mathrm{~m}$. liepos 5 d. nutarimas „Dèl autorinių teisių apsaugos“. Valstybès žinios. 2000, Nr. 56-1669.

27 Lietuvos vyriausiojo administracinio teismo teisejų kolegijos $2006 \mathrm{~m}$. sausio $22 \mathrm{~d}$. nutartis administracineje byloje Nr. $\mathrm{A}^{14}$-86/2006; Lietuvos vyriausiojo administracinio teismo teiseju kolegijos $2008 \mathrm{~m}$. spalio $30 \mathrm{~d}$. nutartis administracineje byloje Nr. $\mathrm{A}^{822}$-1678/2008; Lietuvos 
laikymusi, priimtų administracinių (ar kitų) teisės aktų neprieštaravimu aukštesnès galios teisès aktams ${ }^{28}$; tinkamu valstybės institucijų ir pareigūnų funkcijų vykdymu ${ }^{29}$; mokesčiu surinkimu ${ }^{30}$; finansų sistemos stabilumu ${ }^{31}$; vartotojų, kaip silpnesniosios šalies, gynimu ${ }^{32}$; valstybès paslapties apsauga ${ }^{33}$; valstybinès kalbos vartojimu viešajame Lietuvos gyvenime ${ }^{34}$; geriamojo vandens tiekimu ir nuotekų šalinimu ${ }^{35}$; nekilnojamo turto (ypač žemès sklypų) privatizavimu bei nuosavybès teisès atkūrimu ${ }^{36}$; pagrindinių demokratinių laisvių bei teisių (pavyzdžiui, susirinkimų) apsauga ${ }^{37}$; azartiniais lošimais ${ }^{38}$; žalos atlyginimu iš valstybès biudžeto lěšųu ${ }^{39}$; viešaisiais pirkimais ${ }^{40}$, bankroto bylomis ${ }^{41}$ ir daugelyje kitų sričių (kaip antai šeimos teisès ar ypatingosios

Aukščiausiojo Teismo Civilinių bylų skyriaus teisèjų kolegijos 2011 m. gruodžio 21 d. nutartis civilinèje byloje Nr. 3K-3-523/2011.

28 Lietuvos vyriausiojo administracinio teismo teisèjų kolegijos $2008 \mathrm{~m}$. rugsèjo 26 d. nutartis administracineje byloje $\mathrm{Nr}$. $\mathrm{A}^{575}$-1576/2008.

29 Supra note 22; Lietuvos Aukščiausiojo Teismo Civilinių bylų skyriaus teisèjų kolegijos 2009 m. birželio 26 d. nutartis civilineje byloje Nr. 3K-3-279/2009.

30 Lietuvos vyriausiojo administracinio teismo teisejjų kolegijos $2013 \mathrm{~m}$. spalio $21 \mathrm{~d}$. nutartis administracineje byloje Nr. A442-1721/2013; Lietuvos vyriausiojo administracinio teismo teisèjų kolegijos $2007 \mathrm{~m}$. vasario $26 \mathrm{~d}$. nutartis administracineje byloje Nr. A6-206/2007.

31 Lietuvos Aukščiausiojo Teismo Civilinių bylų skyriaus teisèjų kolegijos 2013 m. gruodžio $23 \mathrm{~d}$. nutartis civilineje byloje Nr. 3K-7-508/2013.

32 Lietuvos Aukščiausiojo Teismo Civilinių bylų skyriaus teisejų kolegijos $2008 \mathrm{~m}$. spalio $28 \mathrm{~d}$. nutartis civilineje byloje Nr. 3K-3-536/2008; Lietuvos vyriausiojo administracinio teismo teisèju kolegijos $2005 \mathrm{~m}$. vasario $22 \mathrm{~d}$. nutartis administracineje byloje Nr. $\mathrm{I}^{1}-01 / 2005$.

33 Lietuvos vyriausiojo administracinio teismo teisèjų kolegijos $2007 \mathrm{~m}$. rugsèjo $10 \mathrm{~d}$. nutartis administracineje byloje Nr. $\mathrm{A}^{14}-741 / 2007$; Lietuvos vyriausiojo administracinio teismo teisèju kolegijos $2008 \mathrm{~m}$. liepos $8 \mathrm{~d}$. nutartis administracinèje byloje Nr. $\mathrm{A}^{502}-704 / 2008$.

34 Lietuvos vyriausiojo administracinio teismo teisejų kolegijos $2008 \mathrm{~m}$. balandžio $15 \mathrm{~d}$. nutartis administracineje byloje Nr. A ${ }^{143}-687 / 2008$.

35 Lietuvos Aukščiausiojo Teismo Civilinių bylų skyriaus teisèjų kolegijos $2013 \mathrm{~m}$. balandžio $5 \mathrm{~d}$. nutartis civilineje byloje Nr. 3K-3-210/2013.

36 Lietuvos Aukščiausiojo Teismo Civilinių bylų skyriaus teisejų kolegijos $2013 \mathrm{~m}$. balandžio 19 d. nutartis civilineje byloje Nr. 3K-3-235/2013; Lietuvos Aukščiausiojo Teismo Civilinių bylų skyriaus teisejų kolegijos $2012 \mathrm{~m}$. lapkričio 15 d. nutartis civilinèje byloje Nr. 3K-7-379/2012.

37 Lietuvos Vyriausiojo administracinio teismo teisèjų kolegijos 2013 m. gruodžio 12 d nutartis administracineje byloje $\mathrm{Nr}$. $\mathrm{A}^{261}-1701 / 2013$.

38 Lietuvos vyriausiojo administracinio teismo teisejų kolegijos $2012 \mathrm{~m}$. lapkričio 8 d. nutartis administracineje byloje Nr. $\mathrm{A}^{662-3070 / 2012}$.

39 Lietuvos vyriausiojo administracinio teismo teisejų kolegijos $2011 \mathrm{~m}$. rugsèjo $5 \mathrm{~d}$. administracinèje byloje Nr. A ${ }^{438}-2281 / 2011$.

40 Lietuvos Aukščiausiojo Teismo Civilinių bylų skyriaus teisèjų kolegijos $2010 \mathrm{~m}$. lapkričio $8 \mathrm{~d}$. nutartis civilinèje byloje Nr. 3K-3-440/2010.

41 Lietuvos Aukščiausiojo Teismo Civilinių bylų skyriaus teisèjų kolegijos $2007 \mathrm{~m}$. birželio $4 \mathrm{~d}$. nutartis civilineje byloje 3K-7-192/2007; Lietuvos Aukščiausiojo Teismo Civilinių bylų skyriaus teisejų kolegijos $2008 \mathrm{~m}$. kovo $26 \mathrm{~d}$. nutartis civilineje byloje 3K-3-166/2008. 
teisenos bylos). Kaip matyti iš teismų praktikos analizès, viešasis interesas egzistuoja ìvairiausiose visuomenès gyvenimo srityse, yra dinamiškas ir kintantis.

Šio straipsnio autoriams tenka sutikti su kai kurių teisès praktikų, atstovaujančių ir teismų sistemai, nuomone, kad viešojo intereso sąvokos įstatymuose apibrèžti nèra galimybès (bent jau kol šiuo klausimu Lietuva seka prancūziškąją tradiciją), nes viešasis interesas yra kintanti kategorija, ir tai, ar konkrečioje byloje egzistuoja viešasis interesas, labai priklauso nuo daugybès individualios situacijos faktinių aplinkybių. Taigi ịstatymų leidejui nepateikus viešojo intereso kategorijos apibrèžties (nepriimant sprendimo pereiti prie vokiškosios tradicijos), o teismams nuolat ad hoc, tačiau kazuistiškai ir ne visuomet ịtikinamai nustatant viešojo intereso (ne)buvimo faktą, iš sukauptos tiek doktrininès, tiek praktinès medžiagos galbūt verta eiti kitu keliu aiškiai identifikuoti tam tikras bylų kategorijas ir tose kategorijose ieškoti ne ad hoc, o nustatyti ex ante žinomus teisinius kriterijus, kuriais vadovaujantis būtų galima nustatyti viešojo intereso buvimo faktą? Tai būtų daug praktiškesnis ir naudingesnis sprendimas, nei nuolat kartoti šabloniškus bei per daug abstrakčius teismų precedentus. Juo labiau, kad ịtikinamų viešojo intereso kategorijos nustatymo teisinių kriterijų paieškos pastangų yra tiek teisès doktrinoje $\mathrm{e}^{42}$, tiek nacionalinių teismų praktikoje $\mathrm{e}^{43}$.

\subsection{Viešojo intereso doktrinos}

Nesant konkrečių ir ịstatymuose ar nacionalinių teismų jurisprudencijoje expressis verbis suformuluotų viešojo intereso gynimo kriterijų yra aktualu bei reikalinga juos susisteminti (suklasifikuoti) vadovaujantis teisès doktrina bei teisine technika.

Teisès doktrinoje pabrèžiama, kad nacionaliniai teismai, nagrinėdami viešojo intereso bylas, vadovaujasi išimtinai subjektyviuoju viešojo intereso nustatymo kriterijumi, tačiau nepagrịstai neatsižvelgia ị objektyvųji (kokybinị, norminị), t. y. nuo teisèjo vidinio įsitikinimo nepriklausantị kriterijų ${ }^{44}$.

Kiekvienas teisès mokslininkas, o ir teisèjai, nagrinejjantys su viešuoju interesu susijusias bylas ar problemas, pateikia pakankamai individualizuotus požiūrius dèl viešojo intereso sampratos doktrinų ịvairovès.

Šio straipsnio autoriai pritaria U. Trumpulio nuomonei, jog galbūt egzistuoja 4 pagrindinès galimai besikristalizuojančios Lietuvos teisinès minties nagrinejjant by-

42 E. Kūris teigè, kad kai bus pakankamai jurisprudencijos, galima bus aiškiai bei nedviprasmiškai apibrèžti, kokie viešojo intereso nustatymo kriterijai jau yra apibrèžti. Kūris, E., supra note 2, p. 51; Nekrošius, V., supra note, p. 1107; Trumpulis, U. Žmogaus individualūs interesai kaip viešojo intereso pagrindas. Jurisprudencija. 2010, 2(6): 131; Krivka, E., supra note 19, p. 50.

43 Lietuvos Aukščiausiojo Teismo Civilinių bylų skyriaus teisèjų kolegijos $2012 \mathrm{~m}$. gruodžio $21 \mathrm{~d}$. nutartis civilineje byloje Nr. 3K-3-603/2012; Lietuvos vyriausiojo administracinio teismo teisèju kolegijos 2013 m. lapkričio 19 d. nutartis administracineje byloje Nr. A ${ }^{822}-1542 / 2013$.

44 Nekrošius, V., supra note 2, p. 1106-1107; Krivka, E., supra note 19, p. 50; Trumpulis, U., opt. cit.; Krivka, E., supra note 6, p. 227; Krivka, E., supra note 2, p. 74 ir kt. 
las, susijusias su viešuoju interesu, viešojo intereso koncepcijos. Anot U. Trumpulio, pagrindinès viešojo intereso koncepcijos yra šios: a) procedūrine; b) daugumos nuomones; c) bendruju vertybiu ir d) bendrojo intereso. Be to, $\mathrm{U}$. Trumpulis akcentuoja, kad bendrųjų vertybių bei bendrojo intereso doktrinos yra vyraujančios Lietuvos Respublikos teismineje jurisprudencijoje $e^{45}$.

Procedūrinè viešojo intereso doktrina yra paremta pagrindine prielaida, kad konkretus sprendimas ir jo sukeltos pasekmès atitiks viešajj interesą, jeigu jis bus priimtas vadovaujantis nustatytomis taisyklemis. Šios doktrinos esmé yra ta, kad tam, jog sprendimas būtų priimtas, pakanka vien to, jog būtų laikytasi procesinių teisės normų, o pasekmių vertinimas nèra svarbus, nes sprendimas, priimamas viešojo intereso labui, kyla iš nustatyto proceso. Tačiau akivaizdu, kad iš šios doktrinos yra pašalintas turiningasis (kokybinis, objektyvusis, norminis) požymis ir pakeičiamas i formalųji viešojo intereso siekiamybès elementą, taip atsiribojant nuo siekiamų tikslų ir rezultatų vertinimo jų realaus vertingumo aspektu, t. y. teisinio reguliavimo veiksmingumas tampa pirminis, formalus ir iš esmès savitikslis dalykas.

Procedūrinè viešojo intereso koncepcija yra žinoma ir užsienio teisès doktrinai ${ }^{46}$, o Lietuvoje procedūrinés viešojo intereso doktrinos esmé atsispindi Viešųjų ir privačiu interesų valstybineje tarnyboje derinimo ịstatymo 2 straipsnio 3 dalyje (asmenys, dirbantys valstybineje tarnyboje, visus sprendimus priima nešališkai ir teisingai), taip pat LAT ${ }^{47}$ ir LVAT ${ }^{48}$ praktikoje. Nors procedūrinè viešojo intereso doktrina teisininkų yra kritikuojama dèl daugelio priežasčių ${ }^{49}$, tačiau šios doktrinos nereikètų visiškai nuvertinti dèl jos požiūrio ị tinkamą teisminị procesąą ${ }^{50}$, nes, pavyzdžiui, vienoje iš LVAT nagrinètų bylų ${ }^{51}$ procedūrinè viešojo intereso doktrina itin pasiteisino ${ }^{52}$. Tačiau daugeliu atveju procedūrinè viešojo intereso doktrina nèra tinkama nagrinèjant bylas, susijusias su viešojo intereso gynimu.

45 Trumpulis, U., supra note 2., p. 225, 228.

46 Feintuck, M., supra note 2, p. 213.

47 Lietuvos Aukščiausiojo Teismo Civilinių bylų skyriaus teisèjų kolegijos $2012 \mathrm{~m}$. lapkričio $15 \mathrm{~d}$. nutartis civilineje byloje Nr. 3K-7-379/2012.

48 Lietuvos vyriausiojo administracinio teismo teiseję kolegijos $2013 \mathrm{~m}$. liepos $17 \mathrm{~d}$. nutartis administracineje byloje $\mathrm{Nr}$. $\mathrm{A}^{525}$-1402/2013; Lietuvos vyriausiojo administracinio teismo teisejų kolegijos $2012 \mathrm{~m}$. spalio $4 \mathrm{~d}$. nutartis administracinèje byloje Nr. A ${ }^{822}-2773 / 2012$.

49 Trumpulis, U., supra note 2, p. 221-222.

50 Ibid., p. 222.

51 Lietuvos vyriausiojo administracinio teismo teisèjų kolegijos $2012 \mathrm{~m}$. spalio 4 d nutartis administracineje byloje Nr. A ${ }^{822}-2773 / 2012$.

52 Prokurorui kreipusis ị teismą prašant panaikinti vienos savivaldybès tarybos sprendimą dèl eksploatuojamų daugiabučių namų bendrosios nuosavybès mokesčių nustatymo, teismas pažymèjo, kad toks savivaldybès sprendimas prieštarauja aukštesnès galios teisès aktams (Civiliniam kodeksui - autoriu pastaba), nes ginčijamas mokestis už teritorijos tvarkymą buvo nustatytas kaip mokestis už bendrosios nuosavybès objektų priežiūros vykdymą, kuris pagal teisinį reguliavimą nebuvo (ir nèra) galimas nustatyti. 
Daugumos nuomonès doktrina grindžiama interesu, kurị palaiko didžioji visuomenès dalis. Manoma, kad individai laikomi geriausiais savo pačių interesų vertintojais, o geriausias tokio teiginio patvirtinimas yra individų išreikšti pageidavimai. Tačiau kaip teisingai pažymi U. Trumpulis ${ }^{53}$, daugumos nuomonès doktrina yra diskriminacinè mažumos atžvilgiu, nes viešasis interesas pakeičiamas daugumos interesu ir taip skatina ne bendros darnos pagrindų kūrimą bei socialinio kompromiso paiešką, o socialinę atskirtị bei polinkị ị nedemokratinị režimą. Netiesiogiai daugumos nuomonès (kiekybinị) kriterijų kritikuoja ir E. Kūris ${ }^{54}$. Daugumos nuomonès problema yra aktuali, pavyzdžiui, rinkimų teisėje, kai mažuma likę parlamentarai turi teisę burtis ị opoziciją, kuriai užtikrinamos didelès veiklos garantijos.

Bendrųjų vertybių doktrina grindžiama viešojo intereso objektyviąja puse, nes susitelkiama ị intereso objektą - vertybę. Viešasis interesas šioje doktrinoje - tai bendra visiems vertybe், kuri yra etinis standartas, tikslas ir etalonas, kurio turi siekti individai, visuomenè bei valstybè. Viešojo intereso paskirtis yra holistinė, t. y. viešasis interesas turi tarnauti visiems. Šios doktrinos postulatų laikosi ir LVAT bei LAT, nes viešąji interesą suvokia kaip tai, kas vertinga ir reikšminga visai visuomenei ar jos daliai, atspindint ir igyvendinant pamatines Lietuvos Respublikos Konstitucijoje

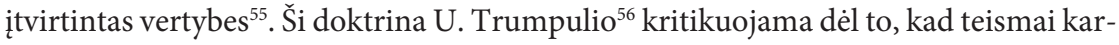
tais pamiršta ịvertinti socialinio gyvenimo dinamiką, neįvertina individualių interesų poveikio viešojo intereso formavimuisi, taip pat neretai paneigia vieną ar kitą Konstitucijoje įtvirtintą principą, vieną iškeliant aukščiau už kitą. Tačiau šio straipsnio autoriai pažymi, kad nacionaliniai teismai suprato socialinio gyvenimo dinamikos svarbą, todèl iš dalies šios doktrinos trūkumas gali būti laikytinas pašalintu ${ }^{57}$.

Bendrojo intereso doktrina teigia, kad viešasis interesas - tai visuma bendru visiems visuomenès nariams interesų, kurie būtų visiems bendri, jeigu kiekvienas visuomenès narys būtų racionalus ir nešališkas. Šioje doktrinoje derinami ir subjektyvieji, ir objektyvieji viešojo intereso elementai. Šios doktrinos taip pat laikosi ir nacionaliniai teismai teigdami, kad spręsdami bylas vadovaujasi bendraisiais visuomenès ir atskirų jos narių interesų derinimo ir individo teisių suvaržymo proporcingumo principais $^{58}$.

Šio straipsnio autoriai taip pat pastebi, kad daugeliu atvejų galètų būti skiriamos ir ekonominė bei socialinė viešojo intereso doktrinos.

53 Trumpulis, U., supra note 2, p. 222. Daugumos kriterijaus kritika taip pat akcentuojama ir kituose šio mokslininko darbuose, pavyzdžiui, Trumpulis, U., supra note 42, p. 131.

54 Kūris, E., supra note 2, p. 49-50.

55 Supra note 4, p. 332-333; supra note 22.

56 Supra note 2, p. 225-226.

57 Supra note 22; Lietuvos vyriausiojo administracinio teismo teisèjų kolegijos $2012 \mathrm{~m}$. balandžio $30 \mathrm{~d}$. nutartis administracineje byloje Nr. $\mathrm{A}^{556}-1517 / 2012$.

58 Lietuvos vyriausiojo administracinio teismo teisejjų kolegijos $2009 \mathrm{~m}$. spalio $22 \mathrm{~d}$. nutartis administracineje byloje Nr. A ${ }^{822}$-1251/2009. 
Ekonominė viešojo intereso doktrina, šio straipsnio autorių nuomone, pasireiškia tuo, kad visos nagrinejjamos bylos, susijusios su viešuoju interesu, yra susijusios tiek su privačių, tiek su viešųjų (pavyzdžiui, valstybès) asmenų ribotais finansiniais ištekliais, jų panaudojimu.

Socialinè viešojo intereso doktrina labiausiai pasireiškia tam tikrų, socialiai jautrių visuomenès grupių atžvilgiu, pavyzdžiui, vartotojų, nepilnamečių, neveiksnių, nuo Sovietų Sąjungos represijos nukentejjusių asmenų bylose.

Atkreiptinas dėmesys, kad tiek ekonominè, tiek socialinè viešojo intereso doktrinos grynu pavidalu neegzistuoja - jos vienokia ar kitokia forma esti kiekvienoje byloje.

Nors nè viena paminèta doktrina iki galo nepaaiškina viešojo intereso sampratos, tačiau kiekvienos doktrinos argumentai bei kritika padeda iškristalizuoti tam tikrus kriterijus arba testus, kuriais vadovaujantis galima būtų nustatyti viešojo intereso egzistavimą konkrečiu atveju. Taigi kokius teisinius kriterijus, remiantis teisés doktrina ir teismų praktika, galima išskirti norint nustatyti, ar konkrečioje byloje egzistuoja tam tikras viešasis interesas, ar jo nèra?

\section{Objektyvieji viešojo intereso nustatymo kriterijai}

Teisinis interesas - tai teisès saugomas ir ginamas subjekto sąmoningas siekis naudojantis teisètomis teisinemis priemonemis ịgyti objektyviai egzistuojantị poreikị patenkinti galintị gèrị (vertybę) $)^{59}$. Teisès subjektai (privatūs asmenys bei valstybė) susaistomi teisiniais santykiais, kurie atspindi gèrių paskirtį (tenkinamus turimus poreikius), pavyzdžiui, valstybė atkuria pareiškẻjams nuosavybès teisę ị okupuotas ar nacionalizuotas jų tèvų žemes. Kalbant tiek apie teisinį, tiek apie viešąji interesą būtina svarstyti ne apie vieno ar kito intereso prioritetą, o apie interesų pusiausvyrą, bendrų vardiklių tarp individualaus ir bendro nustatymą, t. y. interesų bei teisès principų derinimą. Tiek teisinis, tiek viešasis interesas, minèta, nèra tik kiekybinè kategorija, tai kartu ir kokybinè (objektyvi, norminè) kategorija ${ }^{60}$. Jeigu kiekybinį kriterijų galima išreikšti skaičiais, tai natūraliai kyla klausimas, kuo gali būti išreiškiamas kokybinis kriterijus? Šio straipsnio autorių nuomone, kokybiniam viešojo intereso nustatymo kriterijui itin tinkami teisès epistemologijoje jau nuo seno žinomi objektyvieji kriterijai.

Nesigilinant ị teisés moksliškumo ir jos pažinimo problemas ${ }^{61}$, objektyvieji teisès kriterijai yra suprantami kaip kriterijai, kurie nepriklauso nuo subjektyvaus as-

59 Trumpulis, U., supra note 42, p. 126.

60 Kūris, E., supra note 2, p. 53 (žurnalistinès paslapties atskleidimas kai gresia pavojus nors vieno žmogaus gyvybei); Krivka, E., supra note 19, p. 50; Trumpulis, U., supra note 42, p. 131, 133.

61 Mackuvienè, E. Teisès mokslo ir jurisprudencijos moksliškumo problema. Jurisprudencija. 2010, 1(5): 291-304. 
menų vertinimo, t. y. turima omenyje vertybiškai neutralius kriterijus, kurie aprašo socialinès prigimties faktus ${ }^{62}$. Objektyviaisiais kriterijais laikomos teisès normos, ịstatymai, taisyklès ir ịvairūs testai, kuriais verifikuojami arba paneigiami tam tikri socialiniai reiškiniai. Subjektyvieji kriterijai, priešingai objektyviesiems, tai kriterijai, kurie priklauso nuo asmeninių ịsitikinimų, gyvenimiškos patirties ${ }^{63}$, erudicijos ar net altruizmo pojūčio tam tikrose bylose. Iš esmès tokios pat pozicijos laikomasi ir LAT jurisprudencijoje ${ }^{64}$ - subjektyvusis kriterijus yra nulemtas asmeninių savybių ir suvokimo galimybių, o objektyvusis paremtas normaliai rūpestingo, atidaus ir protingo žmogaus (bonus pater familias) suvokimo ir elgesio standarto analogiškoje situacijoje kriterijaus. Tačiau pasakytina, kad objektyvusis kriterijus Lietuvos teisminèje praktikoje suprantamas keliais aspektais.

Pirma, objektyvusis kriterijus gali būti suprantamas kaip bonus pater familias etalonas. Tai reiškia, kad teismai tam tikrą situaciją vertina per protingo bei apdairaus asmens prizmę konkrečioje situacijoje, konkrečiu laiku - kaip analogiškoje bylai situacijoje pasielgtų analogiški ginčo šalims asmenys.

Antra, objektyvusis kriterijus gali būti suprantamas kaip faktas, kuris apskritai nepriklauso nuo asmens pasaulio suvokimo, pavyzdžiui, force majeure, asmens mirtis, metų ir paros kaita, teisès pažeidimo faktas (nepriklauso nei nuo dalyvaujančių byloje šalių, nei nuo teismo ar teisèjo, nei nuo trečiųjų asmenų valios).

Ir, trečia, objektyvusis kriterijus gali būti suprantamas kaip įstatymo imperatyvas.

Iš anksčiau analizuotos teisès doktrinos bei nacionalinès teismų praktikos darytina išvada, kad objektyvieji kriterijai gali būti kiekybiniai ir kokybiniai. Taigi natūraliai kyla klausimas, kokie tiksliai objektyvieji kiekybiniai ir kokybiniai kriterijai egzistuoja nagrinejjant bylas, kylančias iš viešojo intereso gynimo?

\subsection{Viešojo intereso nustatymo teisiniai objektyvieji kiekybiniai kriterijai}

Minèta, kiekybiniai kriterijai dažniausiai išreiškiami matematiniais vienetais. Visuotinai pripažistama, kad interesą turinčių subjektų skaičius nèra vienintelis požymis, pagal kurị viešąji interesą galima išskirti iš kitų interesų ${ }^{65}$. Objektyvumas šiuo atveju suprantamas kaip egzistuojantis teisètas asmens ar asmenų grupès lūkestis, kurị asmuo (asmenų grupė) puoseleja teisinèje valstybejje ir kuris išeina už privataus

62 Ibid., p. 293.

63 Drakšas, R., supra note 2, p. 4.

64 Lietuvos Aukščiausiojo Teismo Civilinių bylų skyriaus teisèjų kolegijos $2013 \mathrm{~m}$. birželio $2 \mathrm{~d}$. nutartis civilineje byloje Nr. 3K-3-375/2013; Lietuvos Aukščiausiojo Teismo Civilinių bylų skyriaus teisejų kolegijos $2010 \mathrm{~m}$. sausio $5 \mathrm{~d}$. nutartis civilinèje byloje Nr. 3K-3-11/2010.

65 Trumpulis, U., supra note 42, p. 131. 
intereso ribų. Tačiau pažymètina, kad būtina tiksliai įvardinti asmenis (pavyzdžiui, nepilnamečiai, neveiksnūs) ar jų grupes (vartotojai, visa visuomenè kaip antai aplinkosaugos ar finansų stabilumo bylose), kurių teisès ar teisèti lūkesčiai yra pažeisti ginčijamose bylose. Taip pat reikètų atsižvelgti ị tai, ar nèra jokių kitų suinteresuotų asmenų, kurių teisès ar teisèti interesai ne hipotetiškai, o realiai gali būti pažeistos, pavyzdžiui, ginčijant nuosavybės teisių atkūrimą vertėtų atsižvelgti, ar yra / nẻra jokių kitų pretendentų atkurti nuosavybès teises ị ginčijamą žemès sklypo dalị. Nesant tokių pretendentų, hipotetiniai svarstymai, manytina, yra pertekliniai ir nereikalingi. Taip pat akcentuotina, kad tam tikrų asmenų skaičių apibrěžia ne hipotetinis tam tikrų, specialiuose ịstatymuose išvardintų subjektų ratas, bet konkretus (realus) subjektų skaičius nagrinejjamojoje byloje. Šiuo požiūriu yra sveikintina LVAT nutartis, kurioje buvo atsisakyta ginti viešąji interesą kilus ginčui, kuriame suinteresuoti bylos baigtimi buvo tik du asmenys ${ }^{66}$, nors jei būtų vadovaujamasi procedūrine viešojo intereso doktrina, viešasis interesas cituojamojoje byloje galètų būti ižzelgtas, nes ịstatymas bei teismų praktika reikalauja besąlyginio ịstatymų ir juose numatytų procedūrų laikymosi. Be kita ko, kitose keliose LVAT nagrinètose bylose ${ }^{67}$ taip pat teisingai pastebèta, jog esant net dideliam trečiųjų suinteresuotų asmenų ratui (byloje buvo net 99 tretieji asmenys), kiekybinis subjektų kriterijus dar nèra vienintelis - būtina atsižvelgti ir ị finansinị (ekonominį) kriterijų, t. y. ịvertinti valstybės finansinius pajègumus ir išteklius, jei būtų taikoma restitucija arba būtų masiškai paduodami ieškiniai valstybei dèl žalos atlyginimo.

Taigi, apibendrinant objektyvųji kiekybinį kriterijų, privalu atsižvelgti ị realų, o ne hipotetinị subjektų ratą, inter alia, net ir nustačius didelị suinteresuotų bylos baigtimi subjektų skaičiuu, dar reiketų įvertinti ir kitus kiekybinius kriterijus, pavyzdžiui, valstybès finansinius resursus. Šio straipsnio autoriai akcentuoja, kad, priklausomai nuo tam tikros kategorijos bylų, kiekybiniai kriterijai gali pasireikšti ir kitomis formomis (ne tik finansiniais ištekliais ar asmenų skaičiumi), pavyzdžiui, tam tikrų atvejų (atsitikimų) skaičiumi ir pan.

\subsection{Viešojo intereso nustatymo teisiniai objektyvieji kokybiniai kriterijai}

Objektyvieji kokybiniai (norminiai) interesai yra išreiškiami tam tikrais teisiniais testais, metodais ar principais. Jie nepriklauso nuo subjektyvaus asmens socialinių reiškinių vertinimo ir, šio straipsnio autorių nuomone, objektyviųjų kokybinių (norminių) kriterijų analizè turètų būti vyraujanti nustatant viešąjị interesą nagrinè-

66 Lietuvos vyriausiojo administracinio teismo teisẻjų kolegijos $2013 \mathrm{~m}$. lapkričio 19 d. sprendimas administracineje byloje Nr. $\mathrm{A}^{822}-1542 / 2013$.

67 Lietuvos vyriausiojo administracinio teismo teisejų kolegijos $2012 \mathrm{~m}$. balandžio $30 \mathrm{~d}$. nutartis administracineje byloje Nr. A ${ }^{556}-1517 / 2012$; supra note 39. 
jamose bylose. Taigi kokie gi galètų būti tie teisiniai objektyvieji kokybiniai (norminiai) interesai, kuriuos visus in corpore kiekvienoje individualioje situacijoje turètų vertinti viešojo intereso bylą nagrinejjantis teismas?

Pirmuoju ir bene svarbiausiu objektyviuoju kokybiniu kriterijumi, manytina, turètų būti laikomas nustatymas fakto, ar yra pažeistos ne bet kokios, o būtent pačios svarbiausios ${ }^{68}$ Konstitucijoje ịtvirtintos vertybès. LVAT akcentuoja, kad viešuoju interesu gali būti laikomas ne bet koks teisètas asmens ar asmenų grupès interesas, o tik toks, kuris atspindi ir išreiškia pamatines visuomenes vertybes, kurias ịtvirtina, saugo ir gina Konstitucija, t. y. viešas interesas yra tuomet, kai pažeidžiamos svarbiausios Konstitucijos ginamos vertybès ${ }^{69}$. Analogiškos pozicijos laikosi ir teisès doktrina ${ }^{70}$.

Antra, nustačius, kad tam tikros vertybès, ịskaitant konstitucines, bet jomis neapsiribojant, yra pažeistos, manytina, kad turi būti nustatyta atitinkamų subjektų, dèl kurių atsirado toks pažeidimas, kaltè. Atkreiptinas dèmesys, kad galimos ịvairios kaltés formos - nuo tyčinès iki didelio neatsargumo ar nerūpestingumo arba apskritai pažeidimas gali būti padarytas klaidingai suvokiant tam tikrus materialaus pasaulio faktus (sąžiningai klystant dèl teisès) arba esant suklaidinimui dèl kitų asmenų pateikiamų faktų, paaiškinimų, ydingos administracinès praktikos taikymo ir panašiai. Tiek $\mathrm{LVAT}^{71}$, tiek $\mathrm{LAT}^{72}$ nagrineddami viešojo intereso bylas pažymėjo, kad turi būti nagrinejjamas atitinkamų subjektų kaltès klausimas dèl priimtų administracinių sprendimų arba sudarytų sandorių. Abiejų kompetencijų teismai laiko, kad tuo atveju, kai yra valstybės institucijų ar jų pareigūnų kaltė, tai valstybė turi prisiimti bet kokių valstybès institucijų padaromų klaidų riziką ir padarytos klaidos negali būti taisomos privataus asmens sąskaita, t. y. tais atvejais, kai tam tikri leidimai ar sandoriai yra panaikinami dèl valstybès institucijų padarytos klaidos (ar dèl valstybès institucijų kaltės), privatūs asmenys neturi dèl to patirti neigiamų pasekmių. Taip pat griežtai, anot LVAT, turi būti vertinamas ir valstybès institucijų neveikimas, kurio atveju valstybès institucija ar pareigūnas, nevykdantis jam priskirtos funkcijos, turi būti atsakingas už atsiradusias tokių veiksmų teisines pasekmes ${ }^{73}$. Tuo atveju,

68 Kokios yra pačios svarbiausios konstitucinès vertybės (jei apskritai galima skirtyti konstitucines vertybes ị svarbesnes ir mažiau svarbias) - diskutuotinas klausimas. Pripažintina, kad žmonių sveikatos apsauga, finansų sistemos stabilumas, pagrindinių demokratinių laisvių bei teisių apsauga yra pamatinès Konstitucinès vertybès.

69 Lietuvos vyriausiojo administracinio teismo išplèstinès teisejų kolegijos $2008 \mathrm{~m}$. liepos $25 \mathrm{~d}$. nutartis administracineje byloje Nr. $\mathrm{A}^{146}-335 / 2008$.

70 Nekrošius, V., supra note 2, p. 1108.

71 Lietuvos vyriausiojo administracinio teismo teisejjų kolegijos $2012 \mathrm{~m}$. spalio $11 \mathrm{~d}$. nutartis administracineje byloje Nr. A ${ }^{552-2758 / 2012 . ~}$

72 Lietuvos Aukščiausiojo Teismo Civilinių bylų skyriaus teisèjų kolegijos 2013 m. liepos 4 d. nutartis civilineje byloje Nr. 3K-3-370/2013.

73 Lietuvos vyriausiojo administracinio teismo teisèjų kolegijos $2012 \mathrm{~m}$. rugsèjo $21 \mathrm{~d}$. nutartis administracineje byloje Nr. AS $^{520}$-648/2012. 
kai svarstomas viešojo administravimo pareigūnų / institucijų kaltès klausimas dèl atliekamų funkcijų pagrịstumo bei teisètumo, aktualūs gali būti ir visuotinai pripažinti gero administravimo principai. LVAT gero administravimo principų reikšmę viešajame administravime nagrinèjo net keliose bylose ${ }^{74}$, o teisès doktrina pateikia visą sąrašą gero administravimo principų ${ }^{75}$. Gero administravimo principų šiurkštus pažeidimas viešojo administravimo srityje suponuoja tai, kad valstybès institucijos prisiima visą neigiamų padarinių atsiradimo riziką.

Taigi kaltès kriterijus viešojo intereso bylose yra itin svarus. Nustačius valstybės institucijų kaltę viešojo intereso gynimas neturètų sukelti neigiamų teisinių pasekmių sąžiningų asmenų atžvilgiu. Nustačius suinteresuotų asmenų kaltę, priešingai, viešasis interesas dominuoja ir turi būti ginamas. Mišrios kaltès situacijoje, t. y. situacija, kai nustatoma tiek valstybės institucijų, tiek suinteresuotų asmenų kaltė, pagelbètų kitų objektyviųjų kiekybinių ir kokybinių kriterijų analizè. Kaltès elementas reikšmingas, tačiau, pažymètina, nẻra vienintelis, taigi mišrios kaltės atveju reikètų vertinti, kuriai pusei yra palankesni kiti objektyvieji (kiekybiniai, kokybiniai) kriterijai. Neatmestinas ir mišrių teisinių pasekmių sprendimas.

Trečia, visuomet būtina vertinti pažeidimo pobūdị, t. y. ar padarytas teisės pažeidimas yra rimtas ir sukeliantis itin neigiamas teisines pasekmes, ar tai tera tik formalus, mažareikšmis pažeidimas. Formalaus (tai ypač būdinga procedūrinei viešojo intereso doktrinai) pažeidimo atveju, šio straipsnio autorių nuomone, viešasis interesas taip pat neturètų būti ginamas, nes nèra kilę jokių teisinių padarinių, pavyzdžiui, žalos ar didelio visuomenès nepasitenkinimo. Kad kiekvienu konkrečiu atveju būtina nustatyti, ar viešasis interesas buvo pažeistas realiai ir ar toks pažeidimas sukèle kokius nors neigiamus teisinius padarinius, vienoje iš savo nutarčių akcentavo ir $\mathrm{LAT}^{76}$. Inter alia, verta paminèti ir Europos Sąjungos konkurencijos teisèje žinomą de minimis taisyklę, kuri mutatis mutandis galètų būti taikytina ir viešojo intereso bylose. De minimis taisyklè teigia, kad jei tam tikri konkurencijos teisès pažeidimai tam tikrose srityse yra mažareikšmiai, tai jiems nèra taikomos atitinkamų (dažniausiai konkurencijos teisés) įstatymų nuostatos ${ }^{77}$. Taigi mutatis mutandis pritaikius šią taisyklę viešojo intereso byloms, akivaizdu, kad apskritai abejotinas viešojo intereso

74 Lietuvos vyriausiojo administracinio teismo teisejų kolegijos $2013 \mathrm{~m}$. gruodžio $10 \mathrm{~d}$. nutartis administracineje byloje Nr. A ${ }^{602}-1902 / 2013$; Lietuvos vyriausiojo administracinio teismo teisejuc kolegijos $2013 \mathrm{~m}$. lapkričio $27 \mathrm{~d}$. nutartis administracinèje byloje $\mathrm{Nr}$. $\mathrm{A}^{525}-2379 / 2013$.

75 Pavyzdžiui, administracinis sąžiningumas, nuoseklumas, kruopštumas, informavimas, pareiga neklaidinti, pareiga paaiškinti, pareiga pagrịsti. Plačiau apie šiuos principus žr. Usher, J. A. Bendrieji Europos Bendrijos teisés prinicipai. Vilnius: Naujoji Rosma, 2001, p. 120-143.

76 Supra note 22.

77 Vègèlè, I. Europos Sajungos teisè. Vidaus rinkos laisvès, konkurencija ir teisés derinimas. Vilnius: VIt Registrų centras, 2011, p. 340. Taip pat žr. 2004 m. gruodžio 9 d. Konkurencijos tarybos nutarimą Nr. 1S-172 „Dèl reikalavimų ir sąlygų susitarimams, kurie dèl savo mažareikšmio poveikio negali itin riboti konkurencijos“. Valstybès žinios. 2000, Nr. 6. (176). 
buvimo faktas, todèl galima konstatuoti, kad viešojo intereso buvimo faktas nèra nustatytas, kai pažeidimai yra formalūs ir / arba mažareikšmiai. Šio straipsnio autorių nuomone, tokiu būdu būtų nešvaistomas itin brangus teismų laikas, taip pat užkirstas kelias besaikès procedūrinès viešojo intereso doktrinos taikymui. Tačiau, užbėgant kritikai už akių, pasakytina, kad formalaus ar mažareikšmio pažeidimo atveju galètų būti pasitenkinama alternatyviais pažeistų teisių gynybos būdais, pavyzdžiui, mokesčių ar finansų teisès bylose kaltajam subjektui galètų būti taikomas įspejjimas, kuris savo ruožtu mokestinėje teisëje sukelia tam tikras neigiamas pasekmes (dažnesnius ir kruopštesnius patikrinimus, mokesčių lengvatų nesuteikimą ir pan.); neteisètos statybos mažareikšmiškumo atveju galima būtų apsiriboti tik tam tikrais ịspejimais arba ippareigojimu ištaisyti trūkumus ateityje arba apskritai apsiriboti vien viešojo intereso pažeidimo konstatavimu (kaip moraline satisfakcija), tačiau tokiu konstatavimu nekeičiant susiklosčiusių teisinių santykių. Pažymėtina, kad viešojo intereso pažeidimo konstatavimas galètų būti vertintinas kaip prejudicinis faktas, atliekant kitas neteismines administracines procedūras bei indikatorius atitinkamiems subjektams taisyti savo klaidas.

Ketvirta, objektyvus kokybinis kriterijus (nors turintis kiekybinio kriterijaus požymių) yra teisinis situacijos ịvertinimas laike, t. y. turètų būti vertinamas laiko tarpas nuo pažeidimo padarymo. Šis kriterijus yra susijęs ir su ieškinio senaties terminais. Šiuo požiūriu yra originali R. Drakšto idèja ${ }^{78}$, kad kai dèl valstybès institucijų (ir ju pareigūnų) kaltės ar netinkamo pareigų atlikimo vèliau prokuratūrai ar kitai valstybès institucijai tenka ginti viešąji interesą, teismai turètų ji atsisakyti ginti, praejjus daugiau kaip trejiems metams (o ne bendrajam dešimties metų terminui) ${ }^{79}$. Tačiau labiausiai dèmesị reikètų atkreipti ị kelias itin sveikintinas nacionalinès teismų praktikos bylas ${ }^{80}$, kuriose konstatuota, kad viešajam interesui esant dinamiškai ir kintančiai kategorijai, turi būti nustatoma, ar viešojo intereso gynimas bylos nagrinėjimo metu yra toks pats aktualus bei svarbus visuomenei (ar jos daliai) jo gynimo metu, kaip tada, kai buvo pažeistas. Tai itin logiškas kriterijus, ypač taikant bonus pater familias etaloną. Akivaizdu, jog taikant bonus pater familias etaloną turètų būti ypač atsižvelgiama ị nagrinèjamo pažeidimo metu egzistavusią socialinę, ekonominę bei politinę padètị, nes priešingu atveju galètume susidurti su situacija, kai vieni dalykai atitinkamu metu buvo traktuojami kaip smerktini, o kiti kaip toleruotini bei vice versa. Toks objektyvusis kokybinis viešojo intereso kriterijus dera ir su nuostata, kad, ginant nuosavybès teisę, ieškinio senatis pradedama skaičiuoti nuo tos dienos, kai asmuo (arba pareigūnas) sužinojo arba turéjo sužinoti apie nuosavybès teisès pažeidimąa ${ }^{81}$ Viena vertus, tai ragina privačius subjektus ginti savo teises tuoj pat, kai suži-

78 Drakšas, R. supra note 2, p. 5.

79 Plačiau apie ieškinio senaties terminus ginant viešąji interesą žr. supra note 4, p. 352-357.

80 Supra note 22; supra note 57.

81 Mikelènas, V., et. al. Civilinè teisé. Bendroji dalis. Vilnius: Justitia, 2009, p. 530. 
nomas pažeidimo faktas, antra vertus, tokia pozicija neleidžia valstybès institucijoms (pareigūnams) ginti viešojo intereso praejjus ilgam laiko tarpui ar iš esmès pasikeitus socialinèms bei ekonominèms šalies aplinkybèms, taip pat susiklosčius teisinių i̇vykių grandinei, pavyzdžiui, sudarius nemažai administracinių sandorių, pirminių administracinių aktų pagrindu prièmus grandinę išvestinių administracinių aktų ir pan.

Penkta, kaip vienas iš objektyviụjų kokybinių viešojo intereso nustatymo kriterijų galètų būti subjektų, padariusių teisès pažeidimą, elgesio vertinimas prieš, per ir po pažeidimo, t. y. ar atitinkami subjektai buvo linkę bendradarbiauti, ar ne, ar padejo išsiaiškinti visas reikiamas aplinkybes, ar priešingai - jas maskavo ir pan. Nors šis elgesio vertinimo laike kriterijus yra būdingesnis sutarčių ir deliktų teisei ${ }^{82}$, tačiau šio straipsnio autoriai mato galimybę mutatis mutandis ši kriterijų taikyti ir viešajam interesui nustatyti, juolab kad šio kriterijaus analizė padeda sušvelninti ar sustiprinti kaltès kriterijaus reikšmę.

Šešta, taip pat vertintinas proporcingumo principas, t. y. ar formalaus pažeidimo padarymas yra pagrindas sugriauti per dešimtmečius nusistovejusią tvarką, paneigti teisinių lūkesčių bei teisinio stabilumo principus, o tiksliau - ar pažeidimas yra tokio pobūdžio, dèl kurio turètų būti paneigiami kiti, išskyrus viešojo intereso, Konstitucijoje ịtvirtinti principai. Proporcingumo principas visuotinai pripažịstamas tiek tarptautineje $^{83}$, tiek nacionalinejje jurisprudencijoje ${ }^{84}$, o teises doktrina proporcingumo

82 Žr., pvz., Lietuvos Aukščiausiojo Teismo teisejų kolegijos $2012 \mathrm{~m}$. balandžio $11 \mathrm{~d}$. nutartị civilinèje byloje Nr. 3K-3-116/2012.

83 Silickis ir Silickienè v. Lietuva, no. 20496/02, ECHR 2012; Althoffand Others v. Germany, no. 5631/05, ECHR 2011.

84 Lietuvos Respublikos Konstitucinio Teismo 1996 m. balandžio 18 d. nutarimas „Dèl Komercinių bankų i̇statymo“. Valstybès žinios. 1996, Nr. 36-915; Lietuvos Respublikos Konstitucinio Teismo 1997 m. vasario 13 d. nutarimas „Dèl alkoholio ir tabako reklamos“. Valstybés žinios. 1997, Nr. 15-314; Lietuvos Respublikos Konstitucinio Teismo 1999 m. kovo 4 d. nutarimas „Dèl SSRS valstybés saugumo komiteto kadrinių darbuotojų darbinès veiklos“. Valstybès žinios. 1999, Nr. 23-666; Lietuvos Respublikos Konstitucinio Teismo 2000 m. sausio 7 d. nutarimas „Dèl savivaldybių teisès nustatyti nuolatines susirinkimų vietas“. Valstybès žinios. 2000, Nr. 3-78; Lietuvos Respublikos Konstitucinio Teismo 2000 m. gruodžio 6 d. nutarimas „Dèl administracinių teisès pažeidimų ir mokesčių administravimo“. Valstybès žinios. 2000, Nr. 1053318; Lietuvos Respublikos Konstitucinio Teismo 2001 m. balandžio 12 d. nutarimas „Dèl leidimo laikyti ir nešioti medžioklini ginklą išdavimo“. Valstybès žinios. 2001, Nr. 33-1108; Lietuvos Respublikos Konstitucinio Teismo 2006 m. rugsèjo 19 d. nutarimas „Dèl žalos, padarytos neteisètos kvotos, tardymo, prokuratūros ir teismo veiksmais, atlyginimo“. Valstybès žinios. 2006, Nr. 90-3529; Lietuvos vyriausiojo administracinio teismo teisèjų kolegijos $2012 \mathrm{~m}$. vasario 6 d. nutartis administracineje byloje $\mathrm{Nr} . \mathrm{A}^{63}$-1221/2012; Lietuvos vyriausiojo administracinio teismo teisèjų kolegijos $2011 \mathrm{~m}$. gruodžio $12 \mathrm{~d}$. nutartis administracinëje byloje Nr. A ${ }^{62}-3753 / 2011$; Lietuvos vyriausiojo administracinio teismo teisejų kolegijos $2011 \mathrm{~m}$. gruodžio $2 \mathrm{~d}$. nutartis administracineje byloje $\mathrm{Nr}$. $\mathrm{A}^{662}-3352 / 2011$; supra note $28 \mathrm{ir} \mathrm{kt}$. 
principą yra analizavusi beveik visais įmanomais pjūviais ${ }^{85}$, todèl išsamesnè proporcingumo principo analizė šiame straipsnyje neatliekama. Tik akcentuotina, kad būtina išlaikyti pusiausvyrą tarp asmens teisès ir viešojo intereso, be to, konstituciniai teisingumo ir teisinès valstybès principai suponuoja ir tai, kad už teisès pažeidimus valstybės nustatomos poveikio priemonès turi būti proporcingos (adekvačios) teisès pažeidimui, turi atitikti siekiamus teisètus ir visuotinai svarbius tikslus, neturi varžyti asmens akivaizdžiai labiau negu reikia šiems tikslams pasiekti.

Septintas objektyvusis kriterijus - testas, kurio metu patikrinama, ar būtų apginta tik subjektinè teisè, atribojant ją nuo įstatymų saugomo intereso. LVAT praktikoje teisingai pastebima ${ }^{86}$, kad viešojo intereso nèra, kai nustatoma, kad ginčijama subjektinè konkrečių asmenų teisé, o ne įstatymų saugomas interesas. Tai motyvuojama tuo, kad ne kiekvienas teisès akto pažeidimas savo pasekmėmis kartu lemia ir viešojo intereso pažeidimą. Plačiau šis kriterijaus dèl tyrimo apimties reikalavimų nebus analizuojamas $^{87}$. Subjektinè teisè turi būti atribojama nuo ne bet kokio, o nuo konstituciškai svarbaus įstatymo saugomo intereso. Minèta, kad viešasis interesas gina ne bet kokị formalų, mažareikšmị ar buitinị interesą (nes tokiems interesams yra numatyti kiti teisiniai instrumentai), o tik konstituciškai svarbų ir reikšmingą, pavyzdžiui, žmogaus teises ir laisves (susirinkimo, žodžio, saviraiškos laisvès), finansų sistemos stabilumą, valstybinių miškų apsaugą ir pan.

Aštunta, LVAT nutarčių ${ }^{88}$ analizè leidžia teigti, kad tam tikrais atvejais objektyviuoju kokybiniu viešojo intereso nustatymo kriterijumi galètų būti EŽTT ar kitų institucijų (net nebūtinai teisminių) tam tikrų „testų“ patikrinimas, t. y. ar taikant visuotinai praktikoje nusistovejusį testą yra tenkinamos testo sąlygos ir viešasis interesas konstatuotinas, ar situacija netenkina atitinkamo testo ir, atitinkamai, nèra konstatuojamas gintinas viešasis interesas. Anksčiau cituotoje byloje buvo iškilęs klausimas dèl susirinkimo teisès ribojimo. LVAT akcentavo, kad susirinkimo laisvès ribojimo taikymo sąlygos (kriterijai) yra nustatyti tiek EŽTT, tiek LRKT jurisprudencijoje - susirinkimų laisvè nèra absoliuti, yra numatyta galimybė riboti šios teisès igyvendinimą, jei toks ribojimas atitinka jam keliamus reikalavimus (žr. cituotą nutartį). Pažymèjęs testo kriterijus, teismas nuodugniai bei išsamiai juos analizavo teisinių padarinių kontekste ir prièjo prie, šio straipsnio autorių nuomone, teisingos išvados. Panašus testas, nustatytas LAT, yra taikomas pareiškus actio Pauliana ieškinị arba

85 Birmontienè, T., et.al. Lietuvos konstitucinè teisé. Vilnius: Mykolo Romerio universitetas, 2002, p. 245, 250-251; Bakaveckas, A. Administracine teisé: teorija ir praktika. Vilnius: Mes, 2012, p. 106-110; Kargaudiené, A. Proporcingumo principas administracinejje teisèje. Jurisprudencija. 2005, 78 (70): 29-38 ir t. t.

86 Lietuvos vyriausiojo administracinio teismo teisejjų kolegijos 2013 m. lapkričio 19 d. nutartis administracineje byloje Nr. A ${ }^{822}$-1542/2013.

87 Plačiau apie subjektinès teisès ir ịstatymo ginamos vertybès atribojimo problematiką žr.: supra note 4, p. 334-339.

88 Supra note 37. 
nustatant priežastinį ryši žalos atlyginimo bylose (conditio sine qua non sąlygos patikrinimas ir teisinio priežastinio ryšio nustatymas). Taigi manytina, kad tam tikrais atvejais tiesiogiai arba mutatis mutandis derètų atsižvelgti ị jau nusistovejusias teisès taikymo taisykles (testus) ir juos atitinkamai pritaikyti situacijai, kai yra ginamas viešasis interesas.

Devinta, kiek silpnesnis, susipynęs su kiekybiniu, objektyvusis kokybinis kriterijus nustatant viešojo intereso buvimo faktą galètų buti ir ekonominis ${ }^{89}$ bei socialinis viešojo intereso aspektas. Minèta, kad viešojo intereso ekonominis bei socialinis interesas yra integralus ir egzistuoja beveik kiekvienoje viešojo intereso doktrinoje, taigi itin pritartina LVAT praktikai ${ }^{90}$, kuri teigia, kad norint ginti viešąji interesą turi būti atsižvelgiama ir ị tą faktą, kad galimai bus naudojamos papildomos (ir, ko gero, neplanuotos) valstybès biudžeto lešos, jeigu būtų reiškiami ieškiniai valstybei dèl žalos atlyginimo ginant viešąji interesą.

Šio straipsnio autorių nuomone, taip pat galima išskirti ir papildomus teisinius objektyviuosius kokybinius kriterijus, kurie gali būti aktualūs bylose, specifiniuose teisiniuose santykiuose. Jie turètų būti vertinami kartu su jau anksčiau minètais devyniais pagrindiniais kriterijais.

Atlikus nacionalinès teismų praktikos analizę, kaip papildomą kriterijų prie pirmojo pagrindinio objektyvaus kokybinio kriterijaus galima būtų skirti patikrinimą fakto, ar ginama vertybè yra išimta iš ịprastos civilinès apyvartos, ar tam tikra veikla yra licencijuojama, ar jai taikomi kitokie suvaržymai (specialus administracinis režimas ar pan.). Tais atvejais, kai teisės objektas yra išimtas iš ịprastos civilinės apyvartos, pavyzdžiui, ginklai, radioakatyvios medžiagos, valstybinès reikšmės miškai, gyvoji gamta arba tam tikrai veiklai taikomas specialus administracinis režimas, pavyzdžiui, licencijavimas, administraciniai leidimai (alkoholio, azartinių lošimų atvejai) ir pan., viešojo intereso egzistavimas yra akivaizdus. Tokios pozicijos laikosi ir LVAT ${ }^{91}$. Nors nacionaliniai teismai tuo atveju, kai viešasis interesas yra susijęs su išimtais iš ịprastos civilinès apyvartos daiktais, pavyzdžiui, valstybinès reikšmès miškais, netaiko mažareikšmiškumo (de minimis) kriterijaus, priimant galutinį sprendimą, būtina nepamiršti ịvertinti ir kitus kriterijus.

Šio straipsnio autoriai pažymi, kad objektyviųjų (tiek kiekybinių, tiek kokybinių) kriterijų gali būti ir daugiau, priklausomai nuo konkrečios bylos faktinių aplinkybių. Prieš priimant sprendimą ginti viešąji interesą, turètų būti atidžiau analizuojami kriterijai, kurių pagalba ir būtų nusprendžiama ginti viešąjị interesą, nes vien mechani-

89 Plačiau apie ekonominę viešojo intereso pusę žr. Murray, R. N. Nuosavybè ir mainai. Viešojo intereso veidai: socialiné, teisine ir ekonominé problematika. Vilnius: Lietuvos laisvosios rinkos institutas ir advokatų kontora LAWIN, 2012, p. 46-57.

90 Supra note 39.

91 Lietuvos vyriausiojo administracinio teismo teisejuc kolegijos $2013 \mathrm{~m}$. spalio 2 d. nutartis administracineje byloje Nr. $\mathrm{A}^{525}$-1561/2013; supra note 38 . 
nis ir inertiškas precedentų citavimas ne visuomet yra tinkamas argumentas viešajam interesui pagrịsti.

\section{Išvados}

Reikia pripažinti, kad viešojo intereso apibrěžties nebuvimas kelia tam tikrą teisinị netikrumą ir nestabilumą. Siekdami eliminuoti viešojo intereso, nustatinėjamo kiekvienoje byloje ad hoc, apibrèžties trūkumus (netikrumą), šio straipsnio autoriai išskiria ex ante pagrindinius objektyviuosius teisinius kriterijus, padedančius nustatyti gintino viešojo intereso egzistavimą.

Ar egzistuoja gintino viešojo intereso buvimo fakto objektyvieji kriterijai, galima nustatyti pasinaudojus dešimties žingsnių taisykle, kuri atitinka formulę: 1 iš 3 kiekybinių kriterijų +9 pagrindiniai kokybiniai kriterijai (+ galimi papildomi kriterijai) = gintinas viešasis interesas.

Vertinant objektyvųj kiekybinị kriterijų privalu atsižvelgti ị realų, o ne hipotetinị subjektų ratą. Net ir nustačius didelị suinteresuotų bylos baigtimi subjektų skaičių, rekomenduotina ịvertinti ir kitus kiekybinius kriterijus - valstybės finansinius išteklius, asmenų skaičių, atvejų skaičių.

Nustačius objektyvųji kiekybinị kriterijų, toliau turètų būti vertinama, ar byloje egzistuoja objektyvieji kokybiniai kriterijai, kurie nustatomi, vadovaujantis toliau pateikiamu algoritmu, įvertinant devynis esminius požymius:

- $\quad$ ar yra pažeistos ne bet kokios, o būtent pačios svarbiausios Konstitucijoje itvirtintos vertybės;

- $\quad$ ar nustatyta atitinkamų subjektų, dèl kurių atsirado toks pažeidimas, kaltè. Jei tai valstybès (savivaldybès) institucijų padarytos klaidos, privatūs asmenys dèl to neturi patirti neigiamų pasekmių;

- ar padarytas teisès pažeidimas yra rimtas ir sukeliantis itin neigiamas teisines pasekmes, ar tai tėra tik formalus, mažareikšmis pažeidimas;

- ar nèra praèjęs ilgas laiko tarpas nuo pažeidimo iki sprendimo prièmimo, dèl kurio galima būtų teigti, kad atitinkamas interesas prarado savo, kaip viešojo intereso požymius, o gal pažeidimo padarymo metu tai nebuvo smerktina situacija;

- $\quad$ ar nèra suejjusi ieškinio senatis;

- $\quad$ ivvertinamas pažeidimą padariusio asmens elgesys prieš, per ir po pažeidimo atlikimo;

- įvertinamas proporcingumo principas - ar pažeidimas yra tokio pobūdžio, dèl kurio turètų būti paneigiami kiti, išskyrus viešojo intereso, Konstitucijoje ịtvirtinti principai;

- $\quad$ ar būtų apginta tik subjektinè teisé, atribojant ją nuo ịstatymų saugomo intereso. Viešojo intereso egzistavimas negali būti konstatuojamas, kai nu- 
statoma, kad ginčijama subjektinė konkrečių asmenų teisé, o ne ịstatymų saugomas interesas;

- $\quad$ ar patikrinti tam tikri testai, t. y. ar taikant visuotinai praktikoje nusistovèjusį testą yra tenkinamos testo sąlygos ir viešasis interesas yra konstatuotinas, ar konkrečių teisinių santykių situacija netenkina tų teisinių santykių mastui būdingo atsakomybès nustatymo ar kito atitinkamo testo;

- $\quad$ ar viešojo intereso gynimas atitinka ekonominị bei socialinị interesus.

Papildomai tam tikrose bylose galètų būti vertinama:

- $\quad$ ar buvo igyvendinti gero administravimo principai viešajame administravime;

- $\quad$ ar ginama vertybė yra išimta iš normalios ir îprastos civilinės apyvartos, ar tam tikra veikla yra licencijuojama, ar jai taikomi kitokie suvaržymai (specialus administracinis režimas ar pan.).

Nustatant viešojo intereso buvimo faktą konkrečioje byloje derètų vadovautis būtent objektyviaisiais teismų praktikoje suformuluotais kriterijais. Žinoma, nereikètų ignoruoti ir kitų - subjektyviųjų kriterijų, tačiau objektyviųjų kriterijų identifikavimas privalo būti atliktas kiekvieną kartą, nes tik tokiu būdu teismo išvada bus itikinamesnè savo argumentacija, bus igyvendintos teisès funkcijos ir tikslai.

\section{Literatūra}

Administracine jurisprudencija. Administraciniu teismy praktika. Administracine doktrina. Lietuvos vyriausiojo administracinio teismo biuletenis. 2009, 6 (16).

Bakaveckas, A. Administracine teisé: teorija ir praktika. Vilnius: Mes, 2012.

Birmontiene, T., et. al. Lietuvos konstituciné teisè. Vilnius: Mykolo Romerio universitetas, 2002.

Drakšas, R. Viešojo intereso gynimas: praktika ir problemos. Lietuvos advokatūra. 2012, 4 (45).

Driukas, A.; Valančius, V. Civilinis procesas: teorija ir praktika. I tomas. Vilnius: Teisinès informacijos centras, 2005.

Europos Žmogaus Teisių Teismo $2011 \mathrm{~m}$. gruodžio $8 \mathrm{~d}$. sprendimas, priimtas ci- vilineje byloje Nr. 5631/05 Althoffand Others v. Germany.

Europos Žmogaus Teisių Teismo 2012 $\mathrm{m}$. balandžio $10 \mathrm{~d}$. sprendimas civilinèje byloje Nr. 20496/02 Silickienè v. Lietuva.

Feintuck, M. The public interest in regulation. Oxford university press, 2004.

Kargaudienė, A. Proporcingumo principas administracineje teiseje. Jurisprudencija. 2005, 78 (70).

Klimas, E.; Brazdeikis, A. Visuomenès (viešojo) intereso gynimas planuojant teritorijas. Viešojo intereso gynimas: subalansuoto požiūrio link. Vilnius: Vilniaus universiteto leidykla, 2013.

Konkurencijos tarybos 2004 m. gruodžio 9 d. nutarimas Nr. 1S-172 „Dèl reikalavimų ir sąlygų susitarimams, kurie 
dèl savo mažareikšmio poveikio negali itin riboti konkurencijos". Valstybès žinios. 2000, Nr. 6. (176).

Krivka, E. Viešojo intereso gynimas civiliniame procese. Vilnius: Mykolo Romerio universitetas, 2009.

Krivka, E. Viešojo intereso gynimo civiliniame procese reglamentavimo problemos. Jurisprudencija. 2008, 2(104).

Kūris, E. Viešasis interesas: teisèkūra ir konstitucinè jurisprudencija. Notariatas. 2012, 13.

Lietuvos Aukščiausiojo Teismo Civilinių bylų skyriaus $2012 \mathrm{~m}$. gruodžio $21 \mathrm{~d}$. nutartis civilineje byloje Nr. 3K-3603/2012.

Lietuvos Aukščiausiojo Teismo Civilinių bylų skyriaus išplèstinès teisèjų kolegijos $2013 \mathrm{~m}$. gruodžio $23 \mathrm{~d}$. nutartis civilineje byloje 3K-7-508/2013.

Lietuvos Aukščiausiojo Teismo Civilinių bylų skyriaus teisèjų kolegijos $2007 \mathrm{~m}$. birželio $4 \mathrm{~d}$. nutartis civilinejje byloje Nr. 3K-7-192/2007.

Lietuvos Aukščiausiojo Teismo Civilinių bylų skyriaus teisèjų kolegijos $2008 \mathrm{~m}$. kovo $26 \mathrm{~d}$. nutartis civilineje byloje $\mathrm{Nr}$. 3K-3-166/2008.

Lietuvos Aukščiausiojo Teismo Civilinių bylų skyriaus teisejjų kolegijos $2008 \mathrm{~m}$. spalio $28 \mathrm{~d}$. nutartis civilinejje byloje Nr. 3K-3-536/2008.

Lietuvos Aukščiausiojo Teismo Civilinių bylų skyriaus teisèjų kolegijos $2009 \mathrm{~m}$. birželio $26 \mathrm{~d}$. nutartis civilinèje byloje Nr. 3K-3-279/2009.

Lietuvos Aukščiausiojo Teismo Civiliniu bylų skyriaus teisèjų kolegijos $2010 \mathrm{~m}$. lapkričio $8 \mathrm{~d}$. nutartis civilinèje byloje Nr. 3K-3-440/2010.

Lietuvos Aukščiausiojo Teismo Civilinių bylų skyriaus teisèjų kolegijos $2010 \mathrm{~m}$. sausio $5 \mathrm{~d}$. nutartis civilinèje byloje Nr. 3K-3-11/2010.

Lietuvos Aukščiausiojo Teismo Civilinių bylų skyriaus teisèjų kolegijos $2011 \mathrm{~m}$. gruodžio $21 \mathrm{~d}$. nutartis civilinejje byloje Nr. 3K-3-523/2011.

Lietuvos Aukščiausiojo Teismo Civilinių bylų skyriaus teisejjų kolegijos $2012 \mathrm{~m}$. balandžio $11 \mathrm{~d}$. nutartis civilinèje byloje Nr. 3K-3-116/2012.

Lietuvos Aukščiausiojo Teismo Civilinių bylų skyriaus teisejjų kolegijos $2012 \mathrm{~m}$. lapkričio $15 \mathrm{~d}$. nutartis civilineje byloje Nr. 3K-7-379/2012.

Lietuvos Aukščiausiojo Teismo Civilinių bylų skyriaus teisejų kolegijos $2013 \mathrm{~m}$. balandžio $19 \mathrm{~d}$. nutartis civilineje byloje Nr. 3K-3-235/2013.

Lietuvos Aukščiausiojo Teismo Civilinių bylų skyriaus teisejjų kolegijos $2013 \mathrm{~m}$. balandžio $5 \mathrm{~d}$. nutartis civilineje byloje Nr. 3K-3-210/2013.

Lietuvos Aukščiausiojo teismo Civilinių bylų skyriaus teisejų kolegijos $2013 \mathrm{~m}$. birželio $2 \mathrm{~d}$. nutartis civilinėje byloje Nr. 3K-3-375/2013.

Lietuvos Aukščiausiojo Teismo Civilinių bylų skyriaus teisèjų kolegijos $2013 \mathrm{~m}$. liepos 4 d. nutartis civilineje byloje $\mathrm{Nr}$. 3K-3-370/2013.

Lietuvos Aukščiausiojo Teismo Civilinių bylų skyriaus teisejų kolegijos $2013 \mathrm{~m}$. vasario $22 \mathrm{~d}$. nutartis civilinèje byloje Nr. 3K-3-40/2013.

Lietuvos Respublikos civilinio proceso kodeksas. Valstybès žinios. 2002, Nr. 36-1340.

Lietuvos Respublikos civilinis kodeksas. Valstybès žinios. 2000, Nr. 74-2262.

Lietuvos Respublikos Konstitucinio Teismo $1996 \mathrm{~m}$. balandžio $18 \mathrm{~d}$. nutarimas "Dèl Komercinių bankų isstatymo“. Valstybès žinios. 1996, Nr. 36-915. 
Lietuvos Respublikos Konstitucinio Teismo $1997 \mathrm{~m}$. vasario $13 \mathrm{~d}$. nutarimas „Dèl alkoholio ir tabako reklamos“. Valstybès žinios. 1997, Nr. 15-314.

Lietuvos Respublikos Konstitucinio Teismo 1999 m. kovo 4 d. nutarimas „Dèl SSRS valstybès saugumo komiteto kadrinių darbuotojų darbinès veiklos“. Valstybès žinios. 1999, Nr. 23-666.

Lietuvos Respublikos Konstitucinio Teismo 2000 m. gruodžio $21 \mathrm{~d}$. nutarimas „Dèl narystès daugiabučių namų savininkų bendrijose“. Valstybès žinios. 2000, Nr. 110-3536.

Lietuvos Respublikos Konstitucinio Teismo 2000 m. gruodžio 6 d. nutarimas „Dèl administracinių teisès pažeidimų ir mokesčių administravimo". Valstybès žinios. 2000, Nr. 105-3318.

Lietuvos Respublikos Konstitucinio Teismo 2000 m. liepos 5 d. nutarimas „Dèl autorinių teisių apsaugos“. Valstybès žinios. 2000, Nr. 56-1669.

Lietuvos Respublikos Konstitucinio Teismo 2000 m. sausio 7 d. nutarimas „Dèl savivaldybių teisès nustatyti nuolatines susirinkimų vietas“. Valstybès žinios. 2000, Nr. 3-78.

Lietuvos Respublikos Konstitucinio Teismo $2001 \mathrm{~m}$. balandžio $12 \mathrm{~d}$. nutarimas „Dèl leidimo laikyti ir nešioti medžioklinị ginklą išdavimo ribojimų“. Valstybès žinios. 2001, Nr. 33-1108.

Lietuvos Respublikos Konstitucinio Teismo 2002 m. kovo $14 \mathrm{~d}$. nutarimas „Dèl farmacinès veiklos“. Valstybès žinios. 2002, Nr. 28-1003.

Lietuvos Respublikos Konstitucinio Teismo 2002 m. rugsejjo $19 \mathrm{~d}$. nutarimas „Dèl Telekomunikacijų, Operatyvinès veiklos istatymų ir Baudžiamojo proceso kodekso“. Valstybès žinios. 2002, Nr. 93-4000.
Lietuvos Respublikos Konstitucinio Teismo 2006 m. rugsèjo 19 d. nutarimas „Dèl žalos, padarytos neteisètais kvotos, tardymo, prokuratūros ir teismo veiksmais, atlyginimo“. Valstybès žinios. 2006, Nr. 90-3529.

Lietuvos Respublikos Konstitucinio Teismo $2006 \mathrm{~m}$. rugsèjo $21 \mathrm{~d}$. nutarimas „Dèl teismų sprendimų motyvų surašymo ir skelbimo, sprendimo už akių, taip pat apeliacijos“. Valstybès žinios. 2006, Nr. 102-3957.

Lietuvos Respublikos prokuratūros îstatymas. Valstybès žinios. 2003, Nr. 421919.

Lietuvos Respublikos Seimo nario Remigijaus Žemaičio $2012 \mathrm{~m}$. balandžio 2 d. pasiūlymas Nr. XP-1963 dèl viešojo intereso gynimo civiliniame ir administraciniame procese [interaktyvus]. [žiūrèta 2014-02-01]. <http:// www3.lrs.lt/pls/inter3/dokpaieska. showdoc_l?p_id=421616>.

Lietuvos Respublikos teritorijų planavimo istatymo pakeitimo istatymas. Valstybés žinios. 2013, Nr. 76-3824.

Lietuvos Respublikos vartotojų teisių apsaugos įstatymas. Valstybès žinios. 1994, Nr. 94-183.

Lietuvos Respublikos viešųjų ir privačių interesų derinimo valstybineje tarnyboje įstatymas. Valstybès žinios. 2000, Nr. 18-431.

Lietuvos vyriausiojo administracinio teismo išplèstinès teisèjų kolegijos 2008 $\mathrm{m}$. liepos $25 \mathrm{~d}$. nutartis administracineje byloje Nr. $\mathrm{A}^{146}-335 / 2008$.

Lietuvos vyriausiojo administracinio teismo teisèjų kolegijos 2005 m. vasario $22 \mathrm{~d}$. nutartis administracineje byloje Nr. $\mathrm{I}^{1}-01 / 2005$.

Lietuvos vyriausiojo administracinio teismo teisèjų kolegijos 2006 m. sausio 22 
d. nutartis administracineje byloje $\mathrm{Nr}$. $\mathrm{A}^{14}$-86/2006.

Lietuvos vyriausiojo administracinio teismo teisèjų kolegijos 2007 m. rugsèjo 10 d. nutartis administracineje byloje Nr. A ${ }^{14}-741 / 2007$.

Lietuvos vyriausiojo administracinio teismo teisejjų kolegijos 2007 m. vasario $26 \mathrm{~d}$. nutartis administracineje byloje Nr. A6 $-206 / 2007$.

Lietuvos vyriausiojo administracinio teismo teisèjų kolegijos 2008 m. balandžio $15 \mathrm{~d}$. nutartis administracinèje byloje Nr. A ${ }^{143}-687 / 2008$.

Lietuvos vyriausiojo administracinio teismo teisejuc kolegijos $2008 \mathrm{~m}$. liepos 8 d. nutartis administracineje byloje Nr. A ${ }^{502}-704 / 2008$.

Lietuvos vyriausiojo administracinio teismo teisejjų kolegijos $2008 \mathrm{~m}$. rugsejjo $26 \mathrm{~d}$. nutartis administracineje byloje Nr. A ${ }^{575}-1576 / 2008$.

Lietuvos vyriausiojo administracinio teismo teisèjų kolegijos 2008 m. spalio $30 \mathrm{~d}$. nutartis administracineje byloje Nr. A ${ }^{822}-1678 / 2008$.

Lietuvos vyriausiojo administracinio teismo teisejuc kolegijos 2009 m. spalio $22 \mathrm{~d}$. nutartis administracineje byloje, Nr. A ${ }^{822}-1251 / 2009$.

Lietuvos vyriausiojo administracinio teismo teisèjų kolegijos 2013 m. lapkričio $19 \mathrm{~d}$. nutartis administracinejje byloje Nr. A ${ }^{822}-1542 / 2013$.

Lietuvos vyriausiojo administracinio teismo teisèjų kolegijos $2011 \mathrm{~m}$. gruodžio $12 \mathrm{~d}$. nutartis administracineje byloje Nr. A ${ }^{62}-3753 / 2011$.

Lietuvos vyriausiojo administracinio teismo teisejų kolegijos $2011 \mathrm{~m}$. gruodžio 2 d. nutartis administracineje byloje Nr. $A^{662}-3352 / 2011$.
Lietuvos vyriausiojo administracinio teismo teisèjų kolegijos $2011 \mathrm{~m}$. rugsejjo 5 d. nutartis administracineje byloje Nr. A ${ }^{438}-2281 / 2011$.

Lietuvos vyriausiojo administracinio teismo teisèjų kolegijos $2012 \mathrm{~m}$. balandžio 30 d. nutartis administracineje byloje Nr. A ${ }^{556}-1517 / 2012$.

Lietuvos vyriausiojo administracinio teismo teisejjų kolegijos $2012 \mathrm{~m}$. lapkričio 8 d. nutartis administracineje byloje Nr. A ${ }^{662}-3070 / 2012$.

Lietuvos vyriausiojo administracinio teismo teisèjų kolegijos 2012 m. rugsèjo $21 \mathrm{~d}$. nutartis administracinèje byloje Nr. AS $^{520}-648 / 2012$

Lietuvos vyriausiojo administracinio teismo teisejju kolegijos 2012 m. spalio $11 \mathrm{~d}$. nutartis administracinejje byloje Nr. A ${ }^{552-2758 / 2012 . ~}$

Lietuvos vyriausiojo administracinio teismo teisejuc kolegijos 2012 m. spalio 4 d. nutartis administracineje byloje Nr. A ${ }^{822}-2773 / 2012$.

Lietuvos vyriausiojo administracinio teismo teisejjų kolegijos 2012 m. vasario 6 d. nutartis administracineje byloje Nr. A ${ }^{63}-1221 / 2012$.

Lietuvos vyriausiojo administracinio teismo teisejjų kolegijos 2013 m. gruodžio 10 d. nutartis administracineje byloje Nr. A ${ }^{602}-1902 / 2013$.

Lietuvos Vyriausiojo administracinio teismo teisejjų kolegijos 2013 m. gruodžio $12 \mathrm{~d}$. nutartis administracinèje byloje Nr. A A $^{261}-1701 / 2013$.

Lietuvos vyriausiojo administracinio teismo teisèjų kolegijos 2013 m. lapkričio 27 d. nutartis administracineje byloje Nr. A ${ }^{525}-2379 / 2013$.

Lietuvos vyriausiojo administracinio teismo teisèjų kolegijos 2013 m. liepos 
$17 \mathrm{~d}$. nutartis administracineje byloje Nr. A ${ }^{525}-1402 / 2013$.

Lietuvos vyriausiojo administracinio teismo teisèjų kolegijos 2013 m. spalio 2 d. nutartis administracineje byloje Nr. $A^{525}-1561 / 2013$.

Lietuvos vyriausiojo administracinio teismo teisèjų kolegijos 2013 m. spalio $21 \mathrm{~d}$. nutartis administracineje byloje Nr. $A^{442}-1721 / 2013$.

Mackuvienė, E. Teisès mokslo ir jurisprudencijos moksliškumo problema. Jurisprudencija. 2010, 1(5).

Mikelènas, V., et. al. Civilinè teisè. Bendroji dalis. Vilnius: Justitia, 2009.

Murray, R. N. Nuosavybė ir mainai. Viešojo intereso veidai: socialine, teisine ir ekonomine problematika. Vilnius: Lietuvos laisvosios rinkos institutas ir advokatų kontora LAWIN, 2012.

Nekrošius, V. Viešojo intereso gynimas civiliniame procese ir konstitucinio teismo doktrina. Jurisprudencija. 2012, 19(3).
Rekosh, E. Who defines the public interest? Public interest law stratiegies ir central and eastern Europe. Sur, Rev. int. direitos human [interaktyvus]. 2005, 2(2) [žiūrèta 2014-02-01]. <http://www.scielo.br/scielo.php?pid $=$ S180664452005000100008\&script $=$ s ci_arttext\&tlng=en $>$.

Trumpulis, U. Viešojo intereso koncepcijų îvairove ir jų vertinimas. Socialiniu mokslu studijos. 2010, 4(8).

Trumpulis, U. Žmogaus individualūs interesai kaip viešojo intereso pagrindas. Jurisprudencija. 2010, 2(6).

Usher, J. A. Bendrieji Europos Bendrijos teisès principai. Vilnius: Naujoji Rosma, 2001.

Vègèlè, I. Europos Sajungos teisè. Vidaus rinkos laisvès, konkurencija ir teisès derinimas. Vilnius: VI Registrų centras, 2011.

Anotacija. Teismams nagrinejant bylas, kuriose yra kilęs viešojo intereso gynimo klausimas, susiduriama su fundamentaliomis viešojo intereso sampratos ir jos turinio problemomis. Teismu praktikoje pasitaiko atvejų, kai skirtingos kompetencijos teismai viešojo intereso gynimo reikalinguma interpretuoja skirtingai, nors ir remdamiesi tomis pačiomis, klasikinèse viešojo intereso bylose suformuluotomis taisyklemis. Darbe, atsižvelgiant ị pagrindines viešojo intereso doktrinas, apibendrintai skiriami pagrindiniai objektyvieji viešojo intereso nustatymo kriterijai.

Reikšminiai žodžiai: viešojo intereso doktrinos, viešojo intereso objektyvieji nustatymo kriterijai, kiekybiniai objektyvieji kriterijai, kokybiniai objektyvieji kriterijai. 


\title{
DETERMINATION OF PUBLIC INTEREST - OBJECTIVE CRITERIA
}

\author{
Evaldas Klimas \\ Mykolas Romeris University, Lithuania \\ Julius Lankelis \\ Mykolas Romeris University, Lithuania
}

Summary. The aim of this article is to identify objective criteria for the determination of public interest concept in the case-law of the Republic of Lithuania. Legal practice and legal doctrine universally agree that there are lot of difficulties defining the concept of public interest. The authors of this study explored that neither statutory law nor case law practice or legal doctrine are able to serve general public interest definition. Despite this fact, the authors tried to determine basic legal objective criteria in order to establish whether the public interest could be established and defended in a particular case.

The article is divided into two main parts.

The comparative doctrine and case law analysis of public interest concept is given in the first part.

The second part includes studies of the precedents of court judgments, where legal objective criteria are identified. The authors established ten basic legal objectives criteria, which may be quantitative and qualitative. In addition, supplementary objective criteria are also crystallised.

This study provides objective legal criteria to identify public interest. These legal objective criteria may serve as a methodical measure for all lawyers to propose a wellreasoned legal conclusion whether the public interest in a particular case exists or not. Firstly, the objective criteria should be determined. Only after that, the algorithm of qualitative objective criteria should be applied. These qualitative objective criteria are the following: was there made the breach of the main constitutional principles; was there determined the fault of subjects; does the breach constitute mightily negative legal consequences; is the defence of public interest still relevant; what are the terms of the limitation period; what were the actions of infringer before, during and after the breach of law; evaluation of the principle of proportionality; dissociation of the subjective right and interest, protected by the law; evaluation of ordinary tests. Additional criteria may also be applied if it is requested in specific legal relationships, e.g., were there implemented the main principles of proper public administration, etc.

Documents analysis and systemic methods were applied during the research. The analysis was supported by teleological and comparative methods.

Keywords: public interest doctrines, objective criteria of public interest concept, quantitative objective criteria, qualitative objective criteria. 
Evaldas Klimas, Mykolo Romerio universiteto Teisès fakulteto Verslo teisès katedros lektorius, teisès mokslų daktaras. Mokslinių tyrimų kryptys: statybos teisé, civilinė teisè.

Evaldas Klimas, Mykolas Romeris University, Faculty of Law, Department of Business Law, lecturer. Research interests: construction law, civil law.

Julius Lankelis, Mykolo Romerio universiteto Teisès fakulteto Verslo teisès magistrantūros nuolatinių studijų studentas. Mokslinių tyrimų kryptis: civilinè ir civilinio proceso teisè.

Julius Lankelis, Mykolas Romeris University, Faculty of Law, student of Business Law Master Programme. Research interests: civil and civil procedure law. 